\title{
Evaluación del Impacto de la Implementación de la Iniciativa Hospital Amigable a los Bebés
}

\author{
ANTÔNIO P. CALDEIRA', EDUARDO GONÇALVES² \\ 1. Doutor. Professor adjunto, Departamento de Saúde da Mulher e da Criança, Universidade Estadual de Montes Claros \\ (UNIMONTES), Montes Claros, MG, Brasil. \\ 2. Especialista. Professor assistente, Departamento de Saúde da Mulher e da Criança, UNIMONTES, Montes Claros, MG,
} Brasil.

\begin{abstract}
Assessment of the Impact of Implementing the Baby-Friendly Hospital Initiative

Objective: To evaluate the impact of the Baby-Friendly Hospital Initiative on the breastfeeding practices of mothers from the urban area of Montes Claros, MG, Brazil. Methods: A comparative analysis was performed of two cross-sectional breastfeeding indicator studies with randomized samples of children under 2 years of age. One study was carried out before and the other after the Baby-Friendly Hospital Initiative had been implemented throughout all public pregnancy and childbirth care services in the city. Kaplan-Meyer survival curves were constructed for different breastfeeding patterns. Log rank testing was used to calculate the level of significance of differences between curves for before and after the Initiative. Results: The survival curves demonstrate that breastfeeding rates increased during the study period. The $\log$ rank test detected significance for increases in all patterns of breastfeeding $(p<0.000)$. Median overall breastfeeding duration increased from 8.9 to 11.6 months and median duration of exclusive breastfeeding rose from 27 days to 3.5 months. Conclusions: Implementation of the Baby-Friendly Hospital Initiative in all public maternity units in Montes Claros significantly increased breastfeeding rates in the city. Since the ideal state of affairs has not yet been reached, further strategies must be implemented to promote and support breastfeeding practices.

(Key words: Breastfeeding, healthcare project and program evaluation, human milk, breastmilk, health promotion).

J. Pediatr. (Rio J.) vol. 83 no. 2 Porto Alegre Mar./Apr. 2007
\end{abstract}

ESTE TRABAJO LO PUEDE ENCONTRAR EN EXTENSO EN WWW.SciELO.CL

Correspondencia a:

Antônio Prates Caldeira

E-mail: antonio.caldeira@unimontes.br 